\title{
Types of Brevipalpus californicus (Banks) (Tenuipalpidae) in Egypt
}

\author{
A. M. Halawa; A. A. Abdallah and A. A. Ebrahim \\ Fruit Acarology Dept., Plant Protec. Res. Inst., Agric. Res. Cent., Giza, Egypt
}

\begin{abstract}
A survey on Brevipalpus californicus (Banks) infesting fruit orchards was conducted in all Egyptian provinces to discover the different types of $B$. californicus in Egypt. Samples were collected from plant foliages, fruits, buds and branches. The study disclosed on presence of two types of the flat mite, B. californicus, as first record in Egypt, and the differences between both of them were discussed.
\end{abstract}

$\underline{\text { Key Words: Tenuipalpidae, Flat Mite, Brevipalpus californicus, Egypt. }}$

\section{INTRODUCTION}

The family Tenuipalpidae has over 622 species in 30 genera describe'- worldwide (Meyer, 1979; Meyer and Gerson, 1980; Ghai and Shenhmar, 1984; Baker and Tuttle, 1987; Ochoa and Salas, 1989; Sepasgosarian, 1990; Evans et al., 1993; Ochoa et al., 1994; Smiley and Gerson, 1995). Baker and Tuttle (1987) identified 165 species of the false spider mites from Mexico, including 117 species in the genus Brevipalpus with 65 new to science. Baker et al. (1975), Smith Meyer (1979), and Baker and Tuttle (1987) divided the genus Brevipalpus into seven species-groups based on the number of dorsolateral hysterosomal setae, number of setae on the palpus, and number of solenidia on tarsus II. Three of these groups include Brevipalpus californicus (Banks), B. obovatus Donnadieu, and $B$. phoenicis (Geijskes). There is concern that a hidden species complex may exist within one or more of these three species:-due to their morphological variations, extensive host lists, geographical distributions, and the number of plant specific viruses they vector. Manson (1967) indicated that variation within species based on the reticulation patterns on the propodosoma and relative length of the dorsal setae appeared to be associated with the host plant.

Baker and Tuttle (1987) reported considerable morphological variation within different populations of $B$. californicus. Morphological variation also has been reported between populations of B. californicus collected in Costa Rica by Ochoa et al. (1994) and B: phoenicis by Ochoa (1985).

Numerous authors have noted intraspecific variation in Brevipalpus spp. especially $B$. californicus, B. obovatus, and B. phoenicis (De Leon, 1961, 1965, 1967; Manson, 1967; Knorr, 1968; Gonzalez, 1975; Baker et al., 1975; Baker and Tuttle, 1987) resulting in numerous synonymous species. Manson (1967) observed a lack of consistency in the reticulation pattern of the female prodorsum and variation in the size and shape of the dorsal setae for all three species. He suggested these variations were associated with differences in host plants. Gonzalez (1975) stated that the same variation could be found within populations of mites collected from a single host plant species. There has been concern that $B$. phoenicis, $B$. californicus, and $B$. obovatus represent a complex group including a number of species (Knorr, 1968; Baker and Tuttle, 1987). There is need for a detailed study of these species, involving both molecular analysis and a comprehensive morphological review. The present study begins to address the latter objective through the use of low-temperature scanning electron microscopy (LTSEM). Currently, the only species shown to vector citrus leprosis is $B$. phoenicis (Rodrigues et al., 2000). We have chosen to focus this study primarily on the morphology of $B$. phoenicis, and making comparisons to $B$. obovatus and B. californicus.

B. californicus was described three times in Egypt by Attiah (1956) as species B. australis Tucker (Zaher, 1984 and Halawa \& Fawzy, 2012). Since then, no survey study has been conducted to revise the classification of $B$. californicus in Egypt, to disclose the presence of the three known types. Ochoa et al. (2013) stated that B. californicus actually represents several species, and the information available in the literature for the true identify of such species in question is now a mystery. Therefore, our study recorded and re-described species B. californicus in Egypt.

\section{MATERIALS AND METHODS}

The survey was conducted on fruit orchards in all Egyptian provinces. At each locality, monthly samples were carried out, from August 2012 to September 2013. Samples were collected from plant 
foliages, fruits, buds and branches and individually bagged in tightly-closed plastic bags and transported on the same day to the laboratory. Mites were removed using a fine hair brush under dissection microscope, then preserved in $70 \%$ ethanol. Selected mites were cleared in Nesbitt solution for 10-12h. Subsequently, mites were mounted on micro-slides in Hoyer's medium, and later dried at $40{ }^{\circ} \mathrm{C}$ for one week (Zhang 2003). The terminology used in the key followed Mesa et al. (2009) and Ochoa et.al (2013). The measurements were given in micrometers $(\mu \mathrm{m})$. The examined materials were deposited as slide-mounted specimens in the mite collection of the Agriculture Research Center, Plant Protection Research Institute, Fruit Acarology Department, Dokki, Egypt (ARC-PPRI).

\section{RESULTS AND DISCUSSION}

\section{Systematics:}

Family Tenuipalpidae Berlese, 1913

Subfamily Brevipalpinae Mitrofanov, 1973

Genus Brevipalpus Donnadieu, 1875

Brevipalpus californicus (Banks, 1904) Synonyms:

Tenuipalpus californicus Banks, 1904: 55.

Tenuipalpus australis Tucker, 1926: 3.

Tenuipalpus vitis Womersley, 1940: 241.

Brevipalpus confusis Baker, 1949: 380.

Brevipalpus browning Baker, 1949: 382.

Brevipalpus woglumi McGregor, 1949: 19

Type 1 of Brevipalpus californicus (Banks, 1904) (Fig.1 A \& B)

Material examined: 5 females and 3 males ex Citrus spp. (Rutaceae), 2 females ex Psidium guajava L. (Myrtaceae), Vitis vinifera L.(Vitaceae) EGYPT: Qalubia province, Tukh district, Moshtohor village, $30^{\circ} 21^{\prime} 18^{\prime \prime} \mathrm{N}, 31^{\circ} 13^{\prime} 30^{\prime \prime} \mathrm{E}, 19$ May 2012 coll. A.M.Halawa; 3 females and 3 males ex Plumeria acutifolia Poir (Apocynaceae), Citrus aurantium L (Rutaceae):EGYPT: Giza province, Nikla village, 30 $02^{\prime} 6^{\prime \prime} \mathrm{N}, 31^{\circ} 12^{\prime} 18^{\prime \prime} \mathrm{E}, 17$ April 2013 coll. A. M. Halaw.

Type 2 of Brevipalpus californicus (Banks, 1904) (Fig. 2 A \& B)

Material examined: 3 females ex Citrus spp. (Rutaceae); 4 females ex Pyrus communis L. (Rosaceae) EGYPT: Behera province, Behera, $30^{\circ} 36^{\prime} 54^{\prime \prime N}, 30^{\circ} 41^{\prime} 6 " \mathrm{E}, 11$ September 2012, coll. A.M. Halawa; 2 females ex Citrus spp. (Rutaceae) EGYPT: Dakahlia province, Tonamel village, $30^{\circ} 50^{\prime} 6^{\prime \prime} \mathrm{N}, 31^{\circ} 15^{\prime} 18^{\prime \prime} \mathrm{E}, 3$ September, 2012, coll. A.M. Halawa.

Remark: The original description of Brevipalpus californicus was given by Banks (1904) from
Redlands, California, and placed under the genus Brevipalpus by McGregor (1949). In Egypt, this species was described as Brevipalpus ustralis Tucker by Attiah (1956), and re-described by Zaher (1984) as B. californicus (Banks), and finally recorded by the first author (2012). Our study agrees with the mentioned descriptions, with exception the differences between the recorded types.

The major characters to differentiate between the two types of $B$. californicus recorded were detailed as follows:

Prodorsum: Propodosoma cuticle in B. californicus type 1 is smooth to wrinkled (rugose) centrally with large closed cells laterally, forming reticulation (Fig.1 A); while in type 2 the prodorsum cuticle entirely reticulate with weaker and faint reticulation centrally, but cells usually closed (Fig. 2 A), some cells fuse to form larger irregular cells .

Opisthsoma : Dorsal opisthosoma in type 1 the cuticle between $\mathrm{cl}-\mathrm{cl}$ and el-elsmooth wrinkled; cuticle posterior e1-elwith a few short, diagonal lines to weak V-shaped folds (fig.1 A); while in type 2 the cuticle between $\mathrm{cl}-\mathrm{c} 1$ and $\mathrm{d} 1-\mathrm{d} 1$ with weak reticulation wrinkled; cuticle between dldland el-elwrinkled to irregularly folded; cuticle posterior e1-e1 irregularly folded with few short transverse folds (V-shaped) (fig. 2 A).

Ventral plate: with medium to small elliptical to circular cells in type 1 (Fig.1 B), whereas the ventral plate in type 2 with medium to large rounded to reticulate cells (Fig.2 B).

Despite the economic importance of genus Brevipalpus, the species remain poorly understood world-wide, Manson (1967), Baker and Tuttle (1987) Ochoa et.al. (1994 \& 2013). This is mainly due to lack of available clear information. This prompted specialists of the family Tenuipalpidae to create a new taxonomic keys in an attempt for checking the accuracy of the taxonomic characters and find further inherited characteristics, which can be reliable in rearranging this group, wherever necessary, and in verification of identification. Consequently, members of the species $B$. californicus world- wide were divided into three types, based on large and clear taxonomic characters anticipation, are to be divided into separate species Ochoa et al. (2013). The differentiation between the three types of $B$. californicus depends on the pattern of cuticle in prodorsum and opisthosoma dorsally and ventral plate ventrally. This study recorded the presence of type 1 in all samples collected and type 2 in some provinces. As for type 3, it was not detected in all samples examined. 


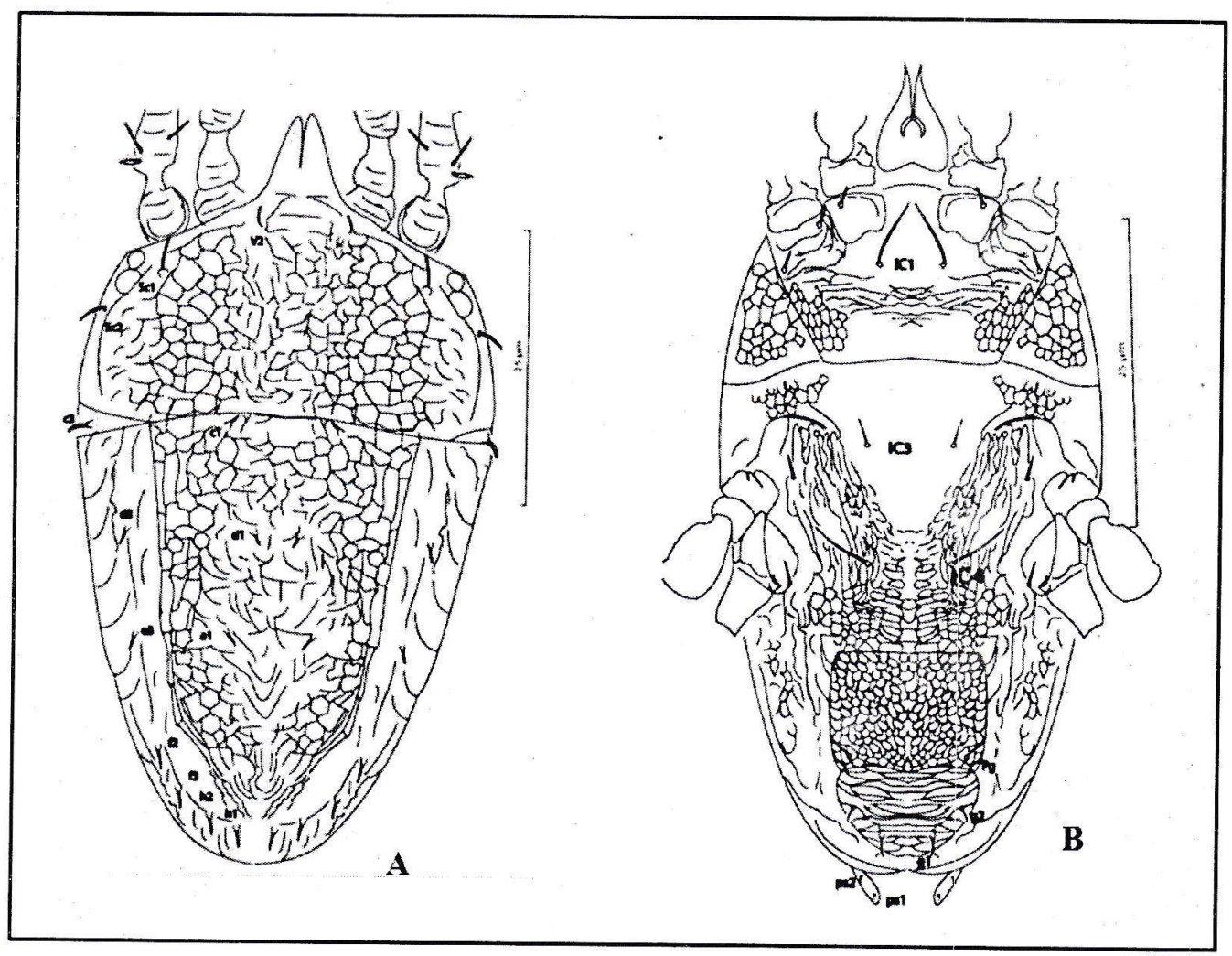

Fig. (1). Brevipalpus californicus type 1, A. Dorsal view, B. ventral view.

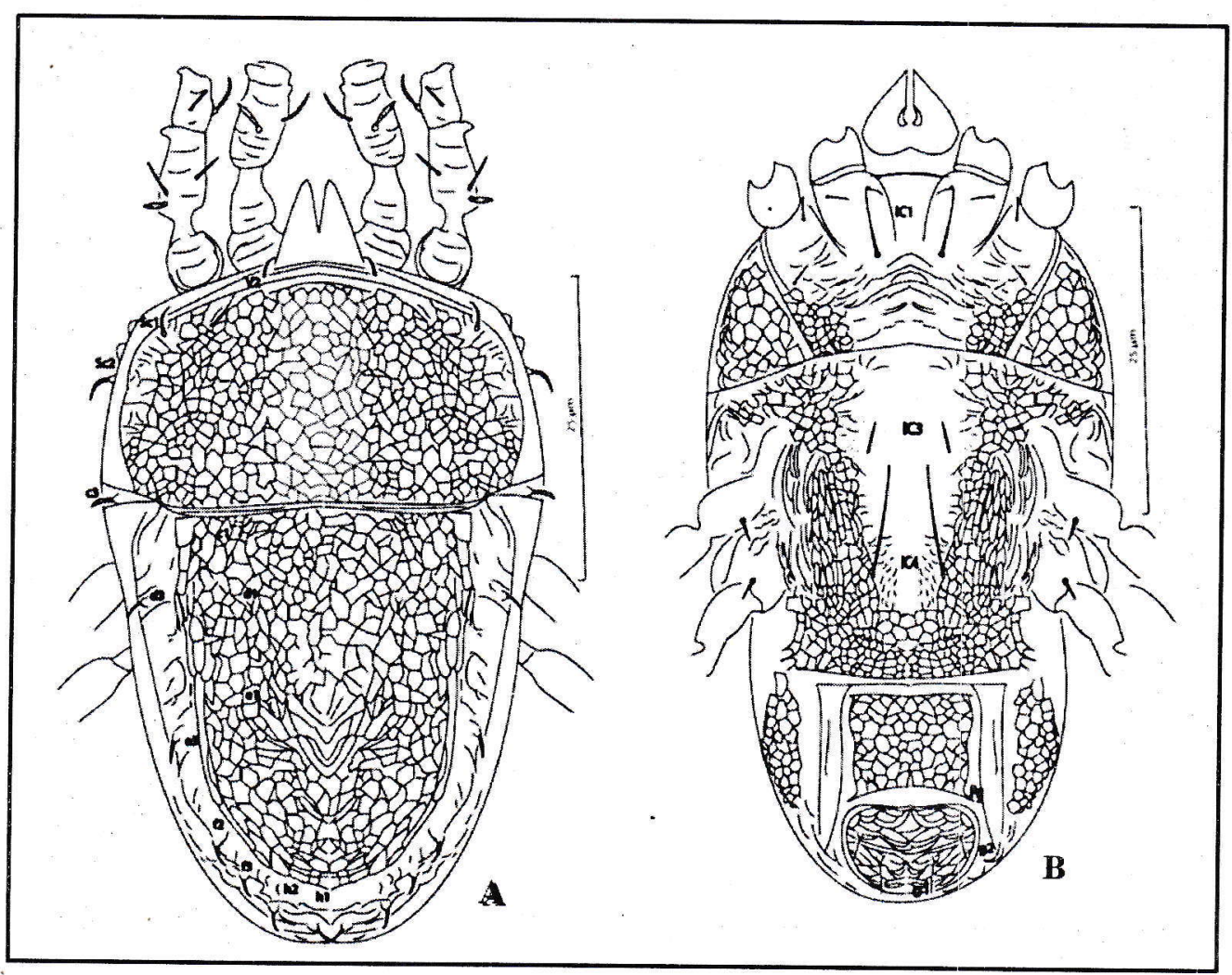

Fig. (2). Brevipalpus californicus type 2, A. Dorsal view, A. ventral view. 


\section{REFERENCES}

Attiah, H. H. 1956. The genus Brevipalpus in Egypt. Bull. Soc. Entom. Egypte, 40: 433-447.

Baker, E.W. 1949. The genus Brevipalpus (Acarina: Pseudoleptidae). Am. Midland Nat., 42:350-402.

Baker, E.W. and Tuttle, D.M. 1987. The false spider mites of Mexico (Tenuipalpidae: Acari). US Dept. Agric. Tech. Bull. No. 1706.

Baker, E.W., Tuttle, D.M. and Abbatiello, M.J. 1975. The false spider mites of northwestern and north central Mexico (Acarina: Tenuipalpidae). Smithsonian Contrib. Zool., 194: 1-23.

Banks, N.1904 Four new species of injurious mites. Journal of the New York Entomological Society, $12,53-56$.

Berlese, A. 1913. Acarotheca Italica. Tipografia di M. Ricci, Firenze, Italy, $221 \mathrm{pp}$.

De Leon, D. 1961. The genus Brevipalpus in Mexico, part II (Acarina: Tenuipalpidae). Fla. Entomol., 44(1): 41-52.

De Leon, D. 1965. New Tenuipalpidae (false spider mites) from British Guiana with notes on four described species. Fla. Entomol., 48(1): 65-75.

De Leon, D. 1967. Some Mites of the Caribbean area. Allen Press, Inc. Lawrence, KS., 66 pp.

Donnadieu, A.L. 1875. Recherches pour servir a l'histoire des Tétranyques. Thèses. Faculté des Sciences de Lyon - Francia, 1-131.

Evans, G.; Cromroy, H.L. and Ochoa, R. 1993. The Tenuipalpidae of Honduras (Tenuipalpidae: Acari). Fla. Entomol., 76: 126-155.

Ghai, S. and Shenhniar, M. 1984. A review of the world fauna of Tenuipalpidae (Acarina: Tetranychoidea). Orient. Insects, 18: 99-172.

Gonzalez, R.H. 1975. Revision of the Brevipalpus phoenicis 'complex' with descriptions of new species from Chile and Thailand (Acarina: Tenuipalpidae). Acarologia, 17(1): 6-91.

Halawa, A.M. and Fawzy, M.H. 2012. A new species of Brevipalpus Donnadieu (Acari: Tenuipalpidae) and key to the Egyptian species. Zootaxa.(In press).

Knorr, L.C. 1968. Studies on the etiology of leprosis in citrus. In: Proc. 4th Conf. Int. Org. Citrus Virol. J.F.L. Childs (ed), p. 332-341. Univ. Fla., Gainesville.

Manson, D.C.M. 1967. Mites of the families Tenuipalpidae and Tetranychidae intercepted entering New Zealand from overseas. New Zealand J. Sci., 10(3): 664-674.

McGregor, E.A. 1949. Nearctic mites of the family Pseudoleptidae. Mem. So. Calif. Sci., 3(2): 1-45.

Mesa, N.C.; Ochoa, R.; Calvin Welbourn; Evans, G.A. and Moraes, G.J. 2009. A Catalog of the Tenuipalpidae (Acari) of the world with a key to the genera. Zootaxa, 2098:1-185.
Meyer, M.K.P. 1979. The Tenuipalpidae (Acari) of Africa with keys to the world fauna. Entomol. Memoir No. 50. Dept. Agric. Tech. Serv. Plant Prot. Res. Inst., Republic of South Africa.

Meyer, M.K.P. and Gerson, U. 1980. Some false spider mites (Prostigmata: Tenuipalpidae) from Israel. Israel J. Entomol., 15: 67-81.

Mitrofanov, V.I. 1973. Revision of the system of phytophagous mites of the subfamily Brevipalpinae (Trombidiformes, Tenuipalpidae). Zoologichesky. Zhurnal., 52(4): 507-511

Ochoa, R. 1985. Reconocimiento preliminar de los acaros fitoparasitos del genero Brevipalpus en Costa Rica. Ing. Agr. Thesis, Facult. De Agronomia, Univ. de Costa Rica, 124 pp.

Ochoa, R. and Salas, L.A. 1989. The genus Brevipalpus in Costa Rica (Acari: Tenuipalpidae). Int. J. Acarol., 15: 21-30.

Ochoa, R.; Aguilar, H. and Vargas, C. 1994. Phytophagous mites of Central America: an illustrated guide. CATIE, Turrialba, Costa Rica, $234 \mathrm{pp}$.

Ochoa, R.; Beard, J.; Bauchan, G.; Matthew, T.; Redford, A.; Walters, T. and Mitter, C. 2013. Flat mites of the world http://idtools.org /id/mites/flatmites.

Rodrigues, Marili V.N.; Rodrigues, Rodney A.F.; Serra, Gil E.; Andritta, Silvio R. and Franco, Telma T. 200. Produção de xarope de açúcar invertido obtido por hidrólise heterogênea através de planejamento experimental. Ciência e Tecnologia dos Alimentos, 20(1): 103-109.

Sepasgosarian, H. 1990. Addendum to a list of the world genera and species of the family Tenuipalpidae (Acari). Entomol. Mitt. Zool. Mus. Hamburg, 10: 85-90.

Smiley, R.L. and Gerson, U. 1995. A review of the Tenuipalpidae (Acari: Prostigmata) of Australia with descriptions of two new genera and four new species. Int. J. Acarol., 21(1): 33-45.

Tucker, M.A. (1926) Some South African Mites. Mainly Tetranychidae and Eriophyidae. Union of South Africa Department of Agriculture, Division of Entomology. Memoir No. V Pretoria, 5: 3-15.

Womersley, H. (1940) Studies in Australian Acarina Tetranychidae and Trichadenidae. Transactions of the Royal Society of South Australia, 64(2): 233-265.

Zaher, M. A. 1984. Phytophagous mites in Egypt. PL.480 Programme U.S.A. Project No. EG-ARS30. Grant No. FG-EG, 228 pp.

Zhang, Z. Q. (2003) Mites of Greenhouses: Identification, Biology and Control. Centre of Agriculture and Biosciences International - Publishing, Wallingford, United Kingdom, 12: 244 pp. 